\title{
Metrics of SI
}

Number of pages: 11

Number of tables: 1

Number of figures: 2

\section{Supporting Information for}

High methane emissions largely attributed to ebullitive fluxes from a subtropical river draining a rice paddy watershed in China

\section{Author list:}

Shuang $\mathrm{Wu}^{1, \mathrm{a}}$, Shuqing $\mathrm{Li}^{1, \mathrm{~b}}$, Ziheng $\mathrm{Zou}^{\mathrm{c}}$, Tao Hu${ }^{\mathrm{a}}$, Zhiqiang $\mathrm{Hu}^{\mathrm{d}}$, Shuwei $\mathrm{Liu}^{\mathrm{a}, \mathrm{b}^{*}}$ and Jianwen $\mathrm{Zou}^{\mathrm{a}, \mathrm{b}}$

\begin{abstract}
Affiliations:
aJiangsu Key Laboratory of Low Carbon Agriculture and GHGs Mitigation, College of Resources and Environmental Sciences, Nanjing Agricultural University, Nanjing, China; ${ }^{\mathrm{b} J i a n g s u ~ K e y ~ L a b ~ a n d ~ E n g i n e e r i n g ~}$ Center for Solid Organic Waste Utilization, Jiangsu Collaborative Innovation Center for Solid Organic Waste Resource Utilization, Nanjing Agricultural University, Nanjing, China; ${ }^{c}$ College of Overseas Education, Nanjing Tech University, Nanjing, China; ${ }^{\mathrm{d} T a i z h o u ~ U n i v e r s i t y, ~ T a i z h o u, ~ C h i n a . ~}$
\end{abstract}

\section{Source of TOC}

A field picture taken by authors was used as TOC/Graphical Abstract

To be submitted to $\boldsymbol{E S \& \boldsymbol { T }}$ 


\section{Supplementary Picture}

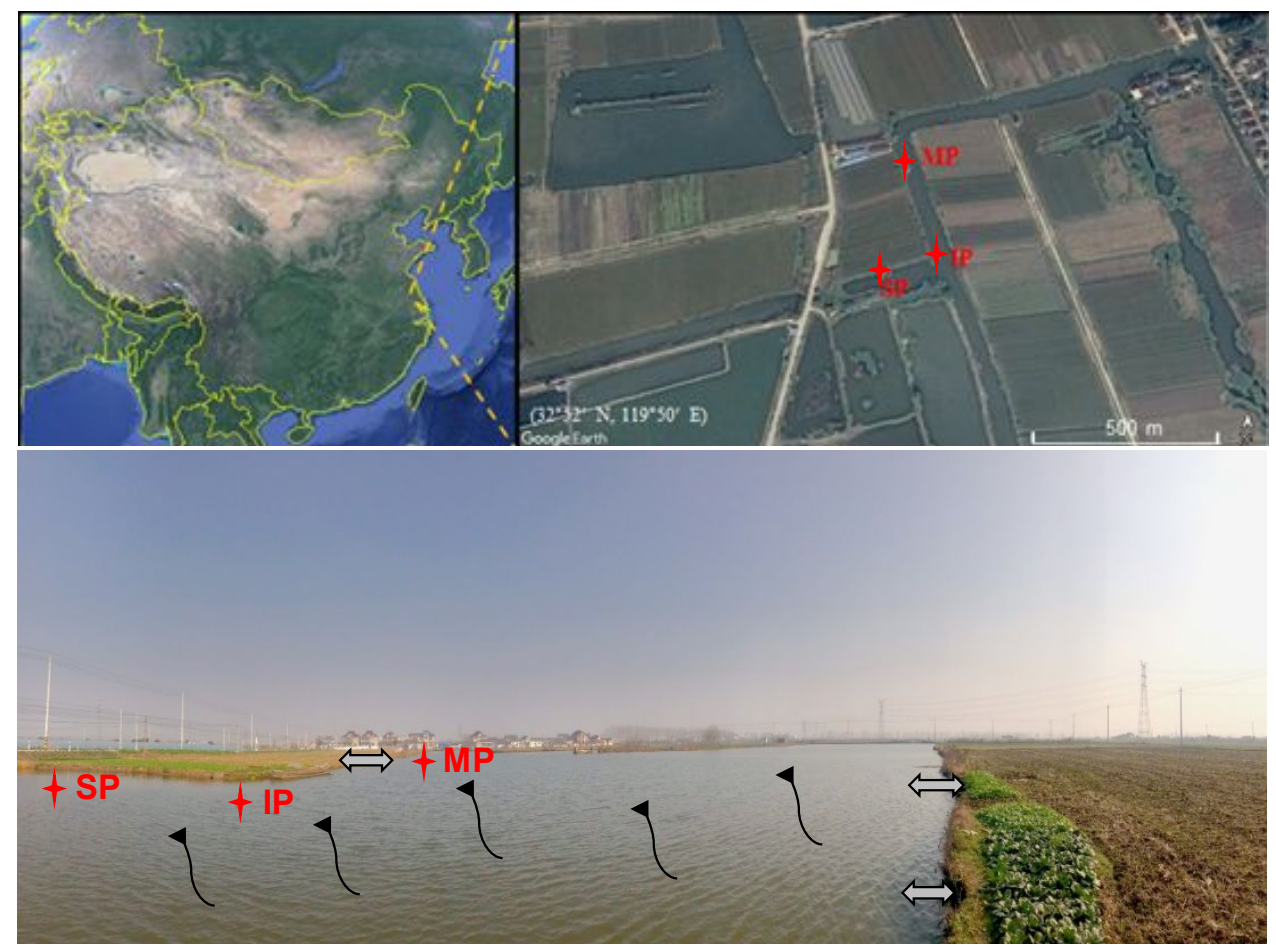

Figure SP. Maps of the measurement sites. The red stars indicate the typical collecting sites for both the gas and surface water samples, including the main-river (MP), intersection (IP) and sideriver points (SP). The black curving arrows indicate the direction of the direction of wind and river flow. Double direction arrows refer to the sites of discharge and withdraw water for drainage and irrigation of rice paddy fields.

\section{Supplementary Texts}

\section{Materials and Methods-Extensive}

$\mathrm{CH}_{4}$ Flux Measurements. The fluxes of $\mathrm{CH}_{4}$ were measured using the floating chamber method from September 15, 2014 to September 15, 2016. Similar to our previous studies on $\mathrm{CH}_{4}$ 
flux measurements in inland aquaculture wetlands, ${ }^{1-4}$ some specially made boardwalks were fixed above the water surface to guarantee access to randomly selected gas sampling sites. Three special floating panels $(0.8 \mathrm{~m}$ length $\times 0.5 \mathrm{~m}$ width $\times 0.15 \mathrm{~m}$ height $)$ made from polyfoam with round bases for each of the three replicated sites were drifted near the boardwalks to keep the entire gas sampling system above the water surface at all times during the observation period. The floating chamber was designed as a column with a height of $0.5 \mathrm{~m}$ and a diameter of $0.25 \mathrm{~m}$. Each chamber was wrapped with a layer of sponge and aluminum foil to minimize air temperature changes inside the chamber during gas sampling. The $\mathrm{CH}_{4}$ fluxes were collected from each chamber into special air-sampling bags (volume 1.5 L) made of inert aluminum-coated plastic using a battery-operated pump (Delin, flow $3 \mathrm{~L} \mathrm{~min}^{-1}$ ) at 0, 5, 10, 15 and 20 min after the chamber closure.

Other Data Measurements. The water dissolved oxygen (DO) concentration was measured using a portable analyzer (HI9146, HANNA CO.). Atmospheric pressure was measured using an electronic barometer on each sampling date (YSI 650 MDS, Yellow Springs, OH, U.S.A). The chemical oxygen demand (COD) concentration of surface water was determined by HACH reaction kits (Loveland, CO., Germany). The water/sediment $\mathrm{pH}$ was determined using a $\mathrm{pH}$ meter (pH610, Germany). The water/sediment dissolved organic carbon (DOC) concentration was measured with ultraviolet-enhanced persulfate digestion and infrared detection (Phoenix 8000, Teledyne Tekmar). The sediment electrical conductivity and organic matter were determined using conductivity meter (FE30, Mettler Toledo) and manual titration method, respectively.

\section{Discussion-Extensive}


Dependence of $\mathrm{CH}_{4}$ Emissions on Water and Sediment Parameters. Typically, the $\mathrm{CH}_{4}$ fluxes were significantly related to water temperature, DO and DOC, as previously documented. 6,7 Water temperature plays an important role in sediment $\mathrm{CH}_{4}$ production and transport efficiency through the water column. ${ }^{8}$ High water DO concentrations often promote $\mathrm{CH}_{4}$ oxidation but inhibit methanogens at the sediment-water interface or during the transportation process. ${ }^{9,10}$ Given that DOC is easily degradable and available to microorganisms, it has been widely considered a dominant factor regulating $\mathrm{CH}_{4}$ production in water. ${ }^{11,12}$

However, it is interesting that $\mathrm{CH}_{4}$ fluxes were positively and significantly related to water $\mathrm{NO}_{3}{ }^{-}-\mathrm{N}$ in the rivers draining rice paddy watersheds (Figure $\mathrm{S} 1$ ). Nitrate could play a dual role as a nutrient and a terminal electron acceptor in regulating $\mathrm{CH}_{4}$ emissions in aquatic systems. ${ }^{13}$ Given that methanogens can be nutrient limited, ${ }^{14}$ high $\mathrm{NO}_{3}^{-}-\mathrm{N}$ may relieve the nutrient limitation and thus facilitate $\mathrm{CH}_{4}$ production in rivers. In addition to its direct effects, $\mathrm{NO}_{3}{ }^{-}-\mathrm{N}$ can indirectly affect $\mathrm{CH}_{4}$ production if algal productivity is nutrient limited. ${ }^{15,16}$ However, the role of $\mathrm{NO}_{3}{ }^{-}-\mathrm{N}$ as an energetically more favourable terminal electron acceptor may have the opposite effect. ${ }^{17,18}$ For example, $\mathrm{NO}_{3}{ }^{-}$can sustain denitrification that is a much more effective metabolic pathway and denitrifiers can outcompete methanogens. Nevertheless, how nutrients affect $\mathrm{CH}_{4}$ dynamics in aquatic systems deserves more attention, particularly its direct and indirect effects in agricultural watersheds.

Sediment parameters also play an important role in driving $\mathrm{CH}_{4}$ fluxes in aquatic systems. Because $\mathrm{CH}_{4}$ is derived from the degradation of organic matter under anaerobic conditions, $\mathrm{CH}_{4}$ fluxes were positively correlated with the sediment organic matter content and DOC content 
(Figure S2c and d), as previously documented in the literature. ${ }^{19}$ Moreover, $\mathrm{CH}_{4}$ fluxes were also correlated to sediment electrical conductivity and $\mathrm{pH}$ when pooling all measurements over the experimental period (Figure S2a and b). Since methanogens are $\mathrm{pH}$-sensitive, they typically grow in a $\mathrm{pH}$ range of 6-8, regulated by agricultural practices in the rivers draining rice paddy watersheds. ${ }^{20}$ The $\mathrm{CH}_{4}$ fluxes were positively related to the sediment electrical conductivity, which was in accordance with results in the saline-alkaline topsoil of the Yellow River Delta. ${ }^{21}$

Mitigation Strategies. Irrigation is of paramount importance to increasing agricultural productivity and has been intensified in a warming world. ${ }^{22}$ The role of aquatic systems draining agricultural watersheds in driving climate change is of increasing concern on the substantial release of greenhouse gases. The obtained $\mathrm{CH}_{4}$ flux measurements were taken only over a limited to a subtropical river draining agricultural watersheds in southeast China, which will therefore prevent us from scaling up average fluxes to national scales. However, $\mathrm{CH}_{4}$ emissions from the rivers draining rice paddy watersheds in this study were remarkably greater than previously reported in rice paddies. Therefore, it is in urgent need to adopt some measures to reduce $\mathrm{CH}_{4}$ emissions from the rivers that drain agricultural watersheds. To this end, the current farming practices could be further optimized to reduce nutrient loads and sediment organic matter enrichment, and thus suppress $\mathrm{CH}_{4}$ generation and effluxes, such as improving fertilization regime and promoting watersaving irrigation in rice paddies. A long-term management option is to reduce watershed soil erosion and nutrient exports from rice paddies by developing water conservancy projects. Another practice can also work by periodically dredging river beds to remove methanogenic sediments and increase water depth. 
Refs: The references included as listed below.

(1) Wu, S.; Hu, Z.; Hu, T.; Chen, J.; Yu, K.; Zou, J.; Liu, S. Annual methane and nitrous oxide emissions from rice paddies and inland fish aquaculture wetlands in southeast China. Atmos. Environ. 2018, 175, 135-144.

(2) Hu, Z.; Wu, S.; Ji, C.; Zou, J.; Zhou, Q.; Liu, S. A comparison of methane emissions following rice paddies conversion to crab-fish farming wetlands in southeast China. Environ. Sci. Pollut. Res. 2016, 23 (2), 1505-1515.

(3) Liu, S.; Hu, Z.; Wu, S.; Li, S.; Li, Z.; Zou, J. Methane and nitrous oxide emissions reduced following conversion of rice paddies to inland crab-fish aquaculture in southeast China. Environ. Sci. Technol. 2016, 50, 633-642.

(4) Gao, J.; Zheng, X.; Wang, R.; Zou, J. Preliminary comparison of the static floating chamber and the diffusion model methods for measuring water-atmosphere exchanges of methane and nitrous oxide from inland water bodies. Clim. Environ. Res. 2014, 19 (3): 290-302. (in Chinese)

(5) Zou, J.; Huang, Y.; Jiang, J.; Zheng, X.; Sass, R. L. A 3-year field measurement of methane and nitrous oxide emissions from rice paddies in China: Effects of water regime, crop residue, and fertilizer application. Global Biogeochem. Cycles 2005, 19 (2), 1-9.

(6) Huttunen, J. T.; Alm, J.; Liikanen, A.; Juutinen, S.; Larmola, T.; Hammar, T.; Silvola, J.; Martikainen, P. J. Fluxes of methane, carbon dioxide and nitrous oxide in boreal lakes and potential anthropogenic effects on the aquatic greenhouse gas emissions. Chemosphere 2003, 52 (3), 609621.

(7) Chen, H.; Yuan, X.; Gao, Y.; Wu, N.; Zhu, D.; Wang, J. Nitrous oxide emissions from newly 
created littoral marshes in the drawdown area of the three gorges reservoir, China. Water. Air. Soil Pollut. 2009, 211 (1-4), 25-33.

(8) Frei, M.; Razzak, M. A.; Hossain, M. M.; Oehme, M.; Dewan, S.; Becker, K. Methane emissions and related physicochemical soil and water parameters in rice-fish systems in bangladesh. Agric. Ecosyst. Environ. 2007, 120 (2-4), 391-398.

(9) Bastviken, D.; Ejlertsson, J.; Tranvik, L. Measurement of methane oxidation in lakes: A comparison of methods. Environ. Sci. Technol. 2002, 36 (15), 3354-3361.

(10) Huttunen, J. T.; Väisänen, T. S.; Hellsten, S. K.; Martikainen, P. J. Methane fluxes at the sediment-water interface in some boreal lakes and reservoirs. Boreal Environ. Res. 2006, 11 (1), $27-34$.

(11) Singh, S. N.; Kulshreshtha, K.; Agnihotri, S. Seasonal dynamics of methane emission from wetlands. Chemosphere-Global Change Sci. 2000, 2 (1), 39-46.

(12) Matveev, A.; Laurion, I.; Deshpande, B. N.; Bhiry, N.; Vincent, W. F. High methane emissions from thermokarst lakes in subarctic peatlands. Limnol. Oceanogr. 2016, 61, 150-164.

(13) Stanley, E. H.; Casson, N. J.; Christel, S. T.; Crawford, J. T.; Loken, L. C.; Oliver, S. K. The ecology of methane in streams and rivers: Patterns, controls, and global significance. Ecol.

Monogr. 2016, 86 (2), 146-171.

(14) Bodelier, P. L. E.; Steenbergh, A. K. Interactions between methane and the nitrogen cycle in light of climate change. Curr. Opin. Environ. Sustain. 2014, 9, 26-36.

(15) Jones, J. B.; Holmes, R. M.; Fisher, S. G.; Grimm, N. B.; Greene, D. M. Methanogenesis in arizona, USA dryland streams. Biogeochemistry 1995, 31 (3), 155-173. 
(16) West, W. E.; Coloso, J. J.; Jones, S. E. Effects of algal and terrestrial carbon on methane production rates and methanogen community structure in a temperate lake sediment. Freshw. Biol. 2012, 57 (5), 949-955.

(17) McCrackin, M. L.; Elser, J. J. Greenhouse gas dynamics in lakes receiving atmospheric nitrogen deposition. Global Biogeochem. Cycles 2011, 25 (4), 1-12.

(18) Megonigal, J. P.; Hines, M. E.; Visscher, P. T. Anaerobic metabolism: Linkages to trace gases and aerobic processes. In Treatise on Geochemistry: Second Edition 2004, pp 317-424.

(19) Crawford, J. T.; Lottig, N. R.; Stanley, E. H.; Walker, J. F.; Hanson, P. C.; Finlay, J. C.; Striegl, R. G.; Winton, V.; Dunbar, G.; Nan, B. $\mathrm{CO}_{2}$ and $\mathrm{CH}_{4}$ emissions from streams in a lake-rich landscape: Patterns, controls, and regional significance. Global Biogeochem. Cycles 2014, 28 (3), $197-210$.

(20) Kelly, C. A.; Rudd, J. W. M.; Furutani, A.; Schindler, D. W.; Jul, N. Effects of lake acidification on rates of organic matter decomposition in sediments effects of lake acidification on rates of organic matter decomposition in sediments. Limnol. Oceanogr. 1984, 29 (4), 687-694.

(21) Zhang, L. H.; Song, L. P.; Zhang, L. W.; Shao, H. B. Diurnal dynamics of $\mathrm{CH}_{4}, \mathrm{CO}_{2}$ and $\mathrm{N}_{2} \mathrm{O}$ fluxes in the saline-alkaline soils of the Yellow River Delta, China. Plant Biosyst. 2015, 149 (4), $797-805$.

(22) Elliott, J.; Deryng, D.; Müller, C.; Frieler, K.; Konzmann, M.; Gerten, D.; Glotter, M.; Flörke, M.; Wada, Y.; Best, N. Constraints and potentials of future irrigation water availability on agricultural production under climate change. Proc. Natl. Acad. Sci. 2014, 111 (9), 3239-3244. 


\section{Supplementary Table}

Table S1. Physicochemical properties of water and sediment $(0-20 \mathrm{~cm} \mathrm{depth})$ in the river

\begin{tabular}{lccccccc}
\hline Variables & Sites & $\mathrm{pH}$ & $\begin{array}{c}\mathrm{DOC} \\
\mathrm{mg} \mathrm{L}-1 / \mathrm{mg} \mathrm{kg}^{-1}\end{array}$ & $\begin{array}{c}\mathrm{TOC} \\
\mathrm{g} \mathrm{L}^{-1} / \mathrm{g} \mathrm{kg}^{-1}\end{array}$ & $\begin{array}{c}\mathrm{TN} \\
\mathrm{g} \mathrm{L}^{-1} / \mathrm{g} \mathrm{kg}^{-1}\end{array}$ & $\begin{array}{c}\mathrm{NH}_{4}^{+}-\mathrm{N}^{\mathrm{N}} \\
\mathrm{mg} \mathrm{L}^{-1} / \mathrm{mg} \mathrm{kg}^{-1}\end{array}$ \\
\hline Water & MP & $7.6 \pm 0.05$ & $112.56 \pm 7.7$ & $9.55 \pm 0.47$ & $1.23 \pm 0.15$ & $4.62 \pm 0.11$ \\
& IP & $7.5 \pm 0.03$ & $103.25 \pm 8.6$ & $9.48 \pm 0.35$ & $1.18 \pm 0.12$ & $4.57 \pm 0.07$ & $5.44 \pm 0.09$ \\
& SP & $7.4 \pm 0.06$ & $104.53 \pm 6.3$ & $9.25 \pm 0.38$ & $1.16 \pm 0.11$ & $4.52 \pm 0.09$ & $5.40 \pm 0.12$ \\
& MP & $6.3 \pm 0.03$ & $151.23 \pm 9.2$ & $13.8 \pm 0.58$ & $1.43 \pm 0.16$ & $6.92 \pm 0.15$ & $9.17 \pm 0.17$ \\
& IP & $6.5 \pm 0.02$ & $146.11 \pm 8.9$ & $13.5 \pm 0.52$ & $1.38 \pm 0.12$ & $6.88 \pm 0.09$ & $9.08 \pm 0.19$ \\
& SP & $6.2 \pm 0.02$ & $141.80 \pm 8.7$ & $13.2 \pm 0.49$ & $1.42 \pm 0.15$ & $6.87 \pm 0.11$ & $9.02 \pm 0.26$ \\
\hline
\end{tabular}




\section{Supplementary Figures}
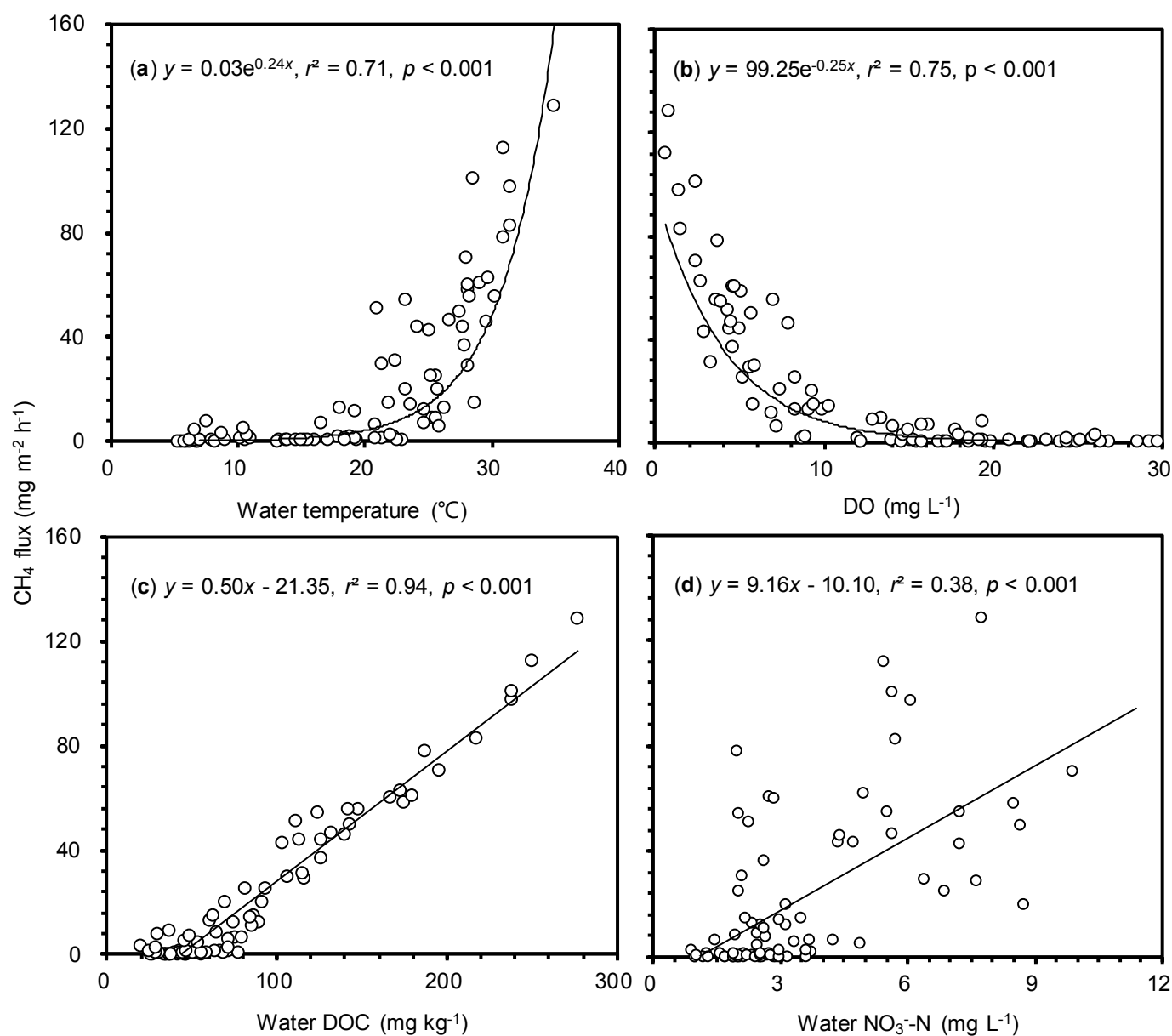

Figure S1. Dependence of $\mathrm{CH}_{4}$ fluxes on water parameters in agricultural irrigation waters. (a) water temperature; (b) water dissolved oxygen (DO); (c) water dissolved organic carbon (DOC); (d) water nitrate concentrations $\left(\mathrm{NO}_{3}^{-}-\mathrm{N}\right)$. 

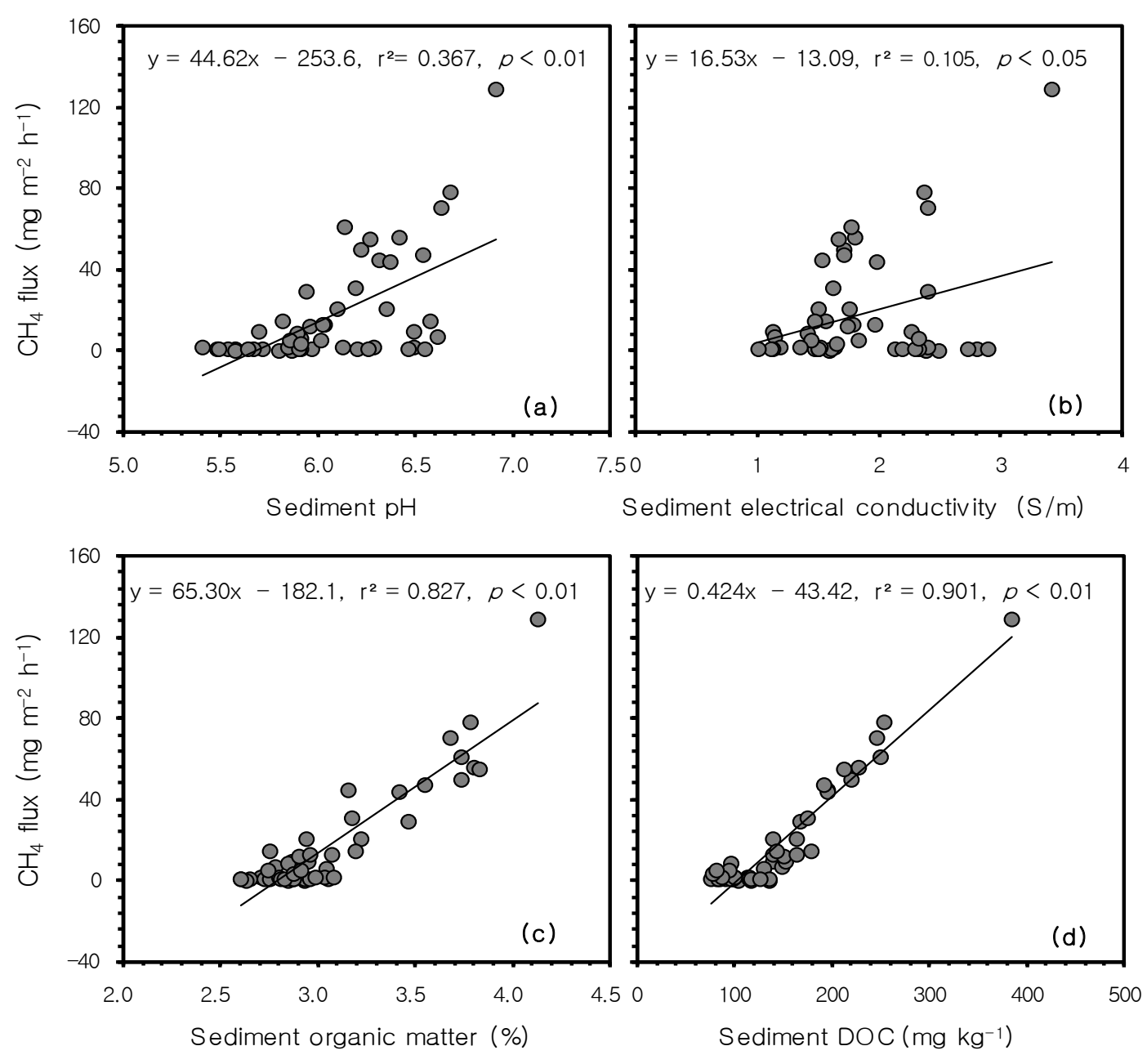

Figure S2. Dependence of $\mathrm{CH}_{4}$ fluxes on sediment parameters in the river draining rice paddy watersheds. (a) sediment pH; (b) sediment electrical conductivity; (c) sediment organic matters; (d) sediment dissolved organic carbon (DOC). 